\title{
Dynamics of changes of nitrogen-bearing joints in well water of Chernivtsi oblast and their link with some agrochemical and agroecological indexes
}

\author{
Rudenko S. \\ Doctor of Biological Sciences, Current PhD students \\ Lakusta 0 \\ Doctor of Biological Sciences, Current PhD students \\ Yu. Fedkovich Chernivtsi national university
}

The purpose. To study the content of nitrogen-bearing joints in well water within the limits of Chernivtsi oblast for 2013-2014 and to analyze their link with some agrochemical and agroecological indexes. Methods. Field, laboratory (potentiometric - for determination of ions $\mathrm{NO}_{3}{ }^{-}$with the use of nitrates-meter $\mathrm{N}-401$; photocolorimetric - for determination of density of $\mathrm{NO}_{2}^{-}$and $\mathrm{NH}_{4}{ }^{+}$with the use of FEK KFK-3), statistical. Results. Nitrate pollution is fixed of the decentralized water service, and also the heightened content of nitrites. By means of the method of principal components it is shown that densities of $\mathrm{NO}_{3}{ }^{-}$and $\mathrm{NH}_{4}{ }^{+}$form joint association with some agrochemical and agroecological indexes. It is fixed basin differences of probed joints within the limits of terrain of Chernivtsi oblast. Conclusions. It is determined that drinking water of Northern Bukovyna belongs to the class of pure and quite pure waters and has congenial ecological state. However within the limits of these characteristics there were certain changes in indexes of density of nitrogen-bearing joints.

Key words: well water, nitrates, nitrites, ammonia, agroecological indexes, agrochemical indexes, Chernivtsi oblast, Dnister, Prut, Siret.

Introduction. The first aquifer from the surface has opening to the wells always. These are groundwater, which accumulate on the near-surface of the waterproof layer. The horizon of these waters is formed by infiltration atmospheric precipitation and water penetrating from surface water objects. These waters belong to the zone of active water exchange. The depth of their occurrence, the regime and the ionic-salt composition caused due to features of the relief, climate, soil and vegetation cover and the specificity of anthropogenic loading $[1,2]$.

The reasons of the modern degradation of the groundwater quality are: the wrong choice of location of the well, non-compliance with the norms of sanitary protection, the flow of contaminated water from cesspits, farms, fields, roads, along with unsatisfactory sanitary and technical care of the well [2].

Using water with a concentration of harmful substances in 3-5 times more then maximum permissible concentrations (MPC) can cause the appearance of initial painful symptoms in the population through 1-2 months; in 10 times - through 2-4 weeks; in 100 times - in a few days [3]. Water pollution with excess nitrate concentrations leads to the emergence of the disease on water-nitrate-methemoglobinemia in children and reduction overall resistance of the organism, which contributes to an increase to the overall disease, including infectious and oncological diseases [5]. It is reported that a positive correlation was found between the level of cardiovascular disease and the content of nitrates [6].

According to $\mathrm{WHO}$, about $80 \%$ of people's illnesses are associated with poor quality drinking water [7-9], but groundwaters in Ukraine are the main source of drinking water supply in rural areas [1]. Therefore, there is no doubt about the actualities of monitoring for the quality of well water.

It is noted that the most complete hydrochemical regime of any reservoir or watercourse reflects the level of nutrients, in the first place Nitrogen and Phosphorus. The high content of these elements leads to a significant deterioration in the state of the aquatic environment [5]. Nitrogen compounds are included in the 
list of major pollutants in accordance with the State Sanitary norms and rules "Hygienic requirements for drinking water intended for human consumption": StSanNiR 2.2.4-400-10 [8].

In addition, a number of studies $[11,12]$ found that water purification from compounds of Nitrogen in the household level is impossible, so people have buying expensive filters cannot provide themselves with highquality water without nitrates. Furthermore, sanitary control by the quality of drinking water from decentralized water supply sources is carried out periodically and selectively [13].

Analysis of recent research and publications on the topic under study. In Ukraine, the studies of the quality of groundwater are carried out by many scientist $[1,3,4,11,14,15]$, while this question remains undiscovered in the territory of Northern Bukovina. After all, today there are separate works on the study of groundwater of the Prut river basin (within the Chernivtsi region) in 2011 [16] and a number of papers by the quality of drinking water of decentralized supply alone in Chernivtsi $[14,17,18]$.

The purpose of research. To estimate the level of agro-loading of Chernivtsi region by the indicator of Nitrogen content in well water and to carry out a comparative analysis of the dynamics of changes in their concentrations in various catchment basins of the main rivers of the region by the period 2013-2014.

Materials and methods of research. The object of our research was the well water of the Chernivtsi region. The territory of region we have been conditionally distributed along the catchment basins of the main rivers of the region - Dniester, Prut and Siret (fig. 1). Sampling was carried out in the summer according to State standard 51593-2000 [19]. The nitrate content was determined potentiometrically with the nitratmetr $\mathrm{H}$ 401, ammonia and nitrites were determined photocolorimetrically using FEC-KFK-3 according to generally accepted methods [20].

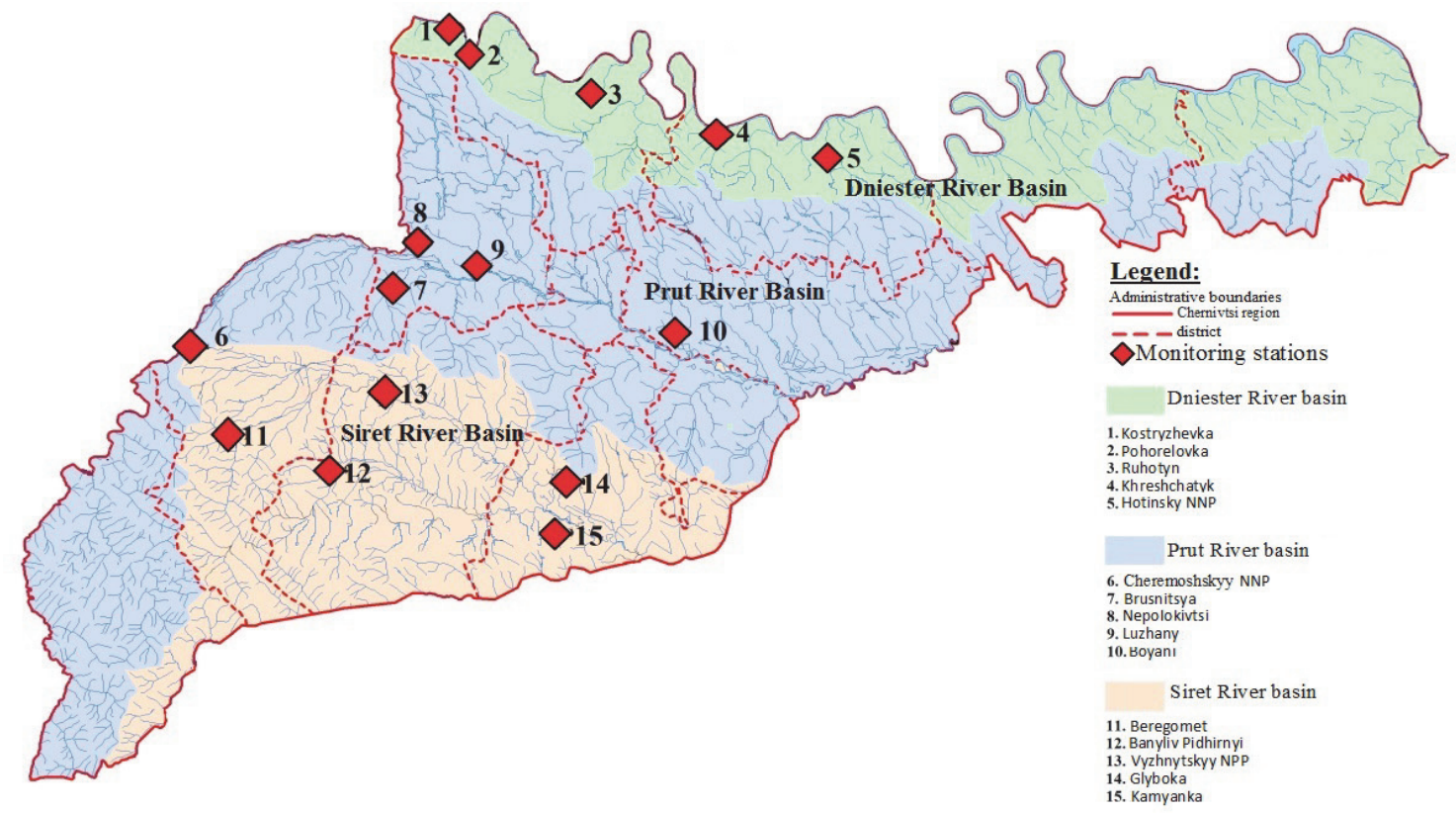

Fig. 1. Monitoring stations within the catchment basins of the main rivers of the Chernivtsi region Dniester, Prut and Siret

The total coefficient of complex pollution $\mathrm{Kz}$ was used, in order to determine the degree of pollution of the studied groundwaters and their ecological status, the following the recommendations and practice of assessing the ecological status of groundwater [21]:

$$
K_{z}=\sum_{1}^{n}\left(\frac{c_{1}}{M P C_{2}}+\frac{C_{2}}{M P C_{2}}+\cdots \frac{C_{n}}{M P C_{n}}\right)(1)
$$

where, $C_{1}, C_{2}, \ldots C_{n}$ - indicators of concentration of various pollutants in groundwater $\left(\mathrm{mg} / \mathrm{dm}^{3}\right) ; \mathrm{MPC}_{1}$, $\mathrm{MPC}_{2}, \ldots \mathrm{MPC}_{\mathrm{n}}$ - maximum permissible concentrations of pollutants in groundwater.

The statistical analysis was carried out using the statistical program Statistica 6.0. The reliability of the difference was estimated using the Mann-Whitney U-criterion [22]. 
Research results. The analysis of the quality of drinking water from decentralized water supply sources in the Chernivtsi region in 2013 based to the nitrate contents has found that the concentration of $\mathrm{NO}_{3}{ }^{-}$ fluctuates within the range of $6,28-155,13 \mathrm{mg} / \mathrm{dm}^{3}$ (table 1), and an average value is $57,39 \pm 13,64 \mathrm{mg} / \mathrm{dm}^{3}$. It is not in accordance with the level of normative indicators set out in StSanNiR 2.2.4-171-10 «Hygienic requirements for drinking water intended for human consumption» [23] and it is higher than the threshold value by $15 \%$. In general, exceeding the MPC level for nitrate contents has been registered in six monitoring stations, namely: Kostryzivka and Pogorilovka - in 3,1 times, Khotinsky NNP - in 2,5 times, Boyany - in 2.2 times, Brusnytsia - in 1.3 times. A slight increase in nitrate ions relative to the norm standards was fixed in the Rukhotyn $(\sim 4 \%)$. It should be noted that the above-mentioned settlements are within the Dniester River basins ( 4 monitoring stations) and the Prut River basins ( 2 monitoring stations).

Therefore, the obtained data was considered in the context of belonging to the catchment basins of the main rivers of the region. There are significantly higher indicators (in 5.2 times) were found in water samples taken from the wells located within the Dniester River basin, in comparison with the Siret River basin.

Table 1. The Nitrogen content in well water in various catchment basins of the main rivers of Chernivtsi region and their total pollution index in 2013

\begin{tabular}{|c|c|c|c|c|}
\hline Monitoring stations & $\begin{array}{r}\mathrm{NO}_{3}^{-} \\
\mathrm{mg} / \mathrm{dm}^{3} \\
(\mathrm{n}=4)\end{array}$ & $\begin{array}{r}\mathrm{NO}_{2}^{-}, \\
\mathrm{mg} / \mathrm{dm}^{3} \\
(\mathrm{n}=4)\end{array}$ & $\begin{array}{r}\mathrm{NH}_{4}^{+}, \\
\mathbf{m g / \mathbf { d m } ^ { 3 }} \\
(\mathrm{n}=4) \\
\end{array}$ & $\mathbf{K}_{\mathbf{z}}$ \\
\hline \multicolumn{5}{|c|}{ Dniester River basin } \\
\hline Kostryzivka & 154,10 & 0,038 & 0,0466 & 3,1 \\
\hline Pogorilovka & 155,13 & 0,041 & 0,0381 & 3,1 \\
\hline Rukhotyn & 51,88 & 0,024 & 0,0248 & 1,1 \\
\hline Khreshchatyk & 19,39 & 0,049 & 0,0296 & 0,4 \\
\hline Khotinsky NNP & 126,0 & 0,038 & 0,0320 & 2,5 \\
\hline \multicolumn{5}{|c|}{ Prut River basin } \\
\hline Boyany & 108,58 & 0,041 & 0,0157 & 2,2 \\
\hline Brusnytsia & 66,36 & 0,978 & 0,0413 & 1,6 \\
\hline Luzhany & 40,35 & 2,832 & 0,0096 & 1,7 \\
\hline Nepolokivtsi & 15,68 & 1,218 & 0,0581 & 0,7 \\
\hline Cheremosh NNP & 25,93 & 2,833 & 0,0111 & 1,4 \\
\hline \multicolumn{5}{|c|}{ Siret River basin } \\
\hline Banilov-Podgorny & 11,83 & 0,414 & 0,0460 & 0,4 \\
\hline Beregomet & 6,28 & 0,108 & 0,0090 & 0,2 \\
\hline Hlyboka & 12,80 & 2,806 & 0,0208 & 1,1 \\
\hline Kamenka & 47,76 & 3,353 & 0,0181 & 2,0 \\
\hline Vyzhnytsky NNP & 18,82 & 0,317 & 0,0084 & 0,5 \\
\hline Maximum permissible concentrations & $\leq \mathbf{5 0}$ & $\leq 3,3$ & $\leq 2,6$ & \\
\hline
\end{tabular}

Note: italics highlighted the MPC excess, according to StSanNiR 2.2.4-171-10

It is known that nitrites $\left(\mathrm{NO}_{2}^{-}\right)$in natural water are usually present in insignificant quantities, and their content does not exceed one thousandth, rarely, tenths of a milligram per cubic decimeter. The presence of nitrites is due to the decomposition processes of organic compounds, mainly by bacterial oxidation of ammonia or the restoration of nitrate nitrogen. Information about the content of nitrites is important for assessing the quality of water, as well as its level of pollution [24].

The study of $\mathrm{NO}_{2}^{-}$concentration in the well water of the Chernivtsi region in 2013 showed that the average indicator of the region is $1,01 \pm 0,33 \mathrm{mg} / \mathrm{dm}^{3}$ (table 1). At the same time, the minimum index was $0,024 \mathrm{mg} / \mathrm{dm}^{3}$, and the maximum is $3.353 \mathrm{mg} / \mathrm{dm}^{3}$. The latter is recorded in water samples selected from. Kamenka. This is the only indicator, which according to StSanNiR 2.2.4-171-10 [23] is somewhat beyond the norm.

It is interesting to note that a significantly higher content of nitrite ions were recorded in samples of water taken from the wells located within the Prut River basin and the Siret River basin (in 42 and 37 times respectively) compared with the well water of the Dniester River basin.

According to the results of the determination of the ammonium ions content in groundwater in the Chernivtsi region in 2013, it was established that the concentration of $\mathrm{NH}_{4}{ }^{+}$varied within $0,0084-0,0581$ 
$\mathrm{mg} / \mathrm{dm}^{3}$. It is fully meets the requirements of StSanNiR 2.2.4-171-10 [23]. Furthermore, differences in the section of catchment basins of the main rivers of the region were not found to be credible.

The application of the total complex pollution indicator $\mathrm{Kz}$ was allowed to establish that the samples of well water in Chernivetsi region in 2013 by the degree of contamination corresponded clean and quite clean criterion, and their ecological status was assessed as favorable (table 1).

Analysis of the Nitrogen compounds content in the well water of various catchment basins of the main rivers of Chernivtsi region in 2014 was showed that no exceedances of normative values were detected (Table 2). In addition, according to the $\mathrm{Kz}$ indicator, drinking water in all monitoring stations belongs to the category of clean water and has a favorable ecological status.

Table 2. The Nitrogens content in well water of various catchment basins of the main rivers of Chernivtsi region and their total pollution indicator in 2014

\begin{tabular}{|c|c|c|c|c|}
\hline Monitoring stations & $\begin{array}{c}\mathrm{NO}_{3}^{-}, \mathrm{mg} / \mathrm{dm}^{3} \\
(\mathrm{n}=4)\end{array}$ & $\begin{array}{c}\mathrm{NO}_{2}^{-}, \mathrm{mg} / \mathrm{dm}^{3} \\
(\mathrm{n}=4)\end{array}$ & $\underset{(n=4)}{\mathrm{NH}_{4}{ }^{+}, \mathrm{mg} / \mathrm{dm}^{3}}$ & $\mathbf{K}_{\mathbf{z}}$ \\
\hline \multicolumn{5}{|c|}{ Dniester River basin } \\
\hline Kostryzivka & 9,83 & 0,513 & 0,0393 & 0,4 \\
\hline Pogorilovka & 8,89 & 0,370 & 0,0276 & 0,3 \\
\hline Rukhotyn & 12,15 & 0,417 & 0,0403 & 0,4 \\
\hline Khreshchatyk & 10,95 & 0,424 & 0,0367 & 0,4 \\
\hline Khotinsky NNP & 12,93 & 0,096 & 0,0342 & 0,3 \\
\hline \multicolumn{5}{|c|}{ Prut River basin } \\
\hline Boyany & 11,05 & 0,424 & 0,0511 & 0,4 \\
\hline Brusnytsia & 7,63 & 0,338 & 0,0320 & 0,3 \\
\hline Luzhany & 10,15 & 0,164 & 0,0421 & 0,3 \\
\hline Nepolokivtsi & 10,2 & 0,657 & 0,0384 & 0,4 \\
\hline Cheremosh NNP & 7,72 & 0,164 & 0,0327 & 0,2 \\
\hline \multicolumn{5}{|c|}{ Siret River basin } \\
\hline Banilov-Podgorny & 10,55 & 0,479 & 0,1528 & 0,4 \\
\hline Beregomet & 11,98 & 0,413 & 0,0426 & 0,4 \\
\hline Hlyboka & 10,27 & 0,354 & 0,0811 & 0,3 \\
\hline Kamenka & 10,75 & 0,451 & 0,0600 & 0,4 \\
\hline Vyzhnytsky NNP & 10,05 & 0,140 & 0,0345 & 0,3 \\
\hline Maximum permissible concentrations & $\leq \mathbf{5 0}$ & $\leq 3,3$ & $\leq 2,6$ & \\
\hline
\end{tabular}

Studies of the content of the nitrogen compounds of the well waters of the region in 2014 has revealed an ambiguous situation. Thus, the concentration of $\mathrm{NO}_{3}^{-}$is significantly reduced (in 5,55 times, $\mathrm{p}<0,05$ ) in comparison with the previous year and reaches the mark $10,34 \pm 0,38 \mathrm{mg} / \mathrm{dm}^{3}$ Instead, the level of $\mathrm{NH}_{4}{ }^{+}$is significantly increased (in 1,67 times) for the period $2013-2014$ and it is $0,05 \pm 0,01 \mathrm{mg} / \mathrm{dm}^{3}$. In addition, ammonia performance were in 2,1 times higher $(p<0,05)$ in the well water of the Dniester River basin compared with similar data from the Siret River basin.

Annual differences of the content of $\mathrm{NO}_{2}{ }^{-}$for the period 2013-2014 is not statistically verified.

It was shown that In the well water of the Chernivtsi region there is an increased level of nitrite ions in comparison with other regions of the Ukraine (table 3).

Table 3. Comparative content of Nitrogen compounds in well water in Chernivtsi region and some regions of Ukraine

\begin{tabular}{|c|l|c|c|c|}
\hline Year & & $\mathbf{N O}_{3}{ }^{-}$ & $\mathbf{N O}_{\mathbf{2}}{ }^{-}$ & $\mathbf{N H}_{\mathbf{4}}{ }^{+}$ \\
\hline 2013 & Chernivtsi region & $6,28-155,13$ & $0,02-3,35$ & $0,01-0,06$ \\
\hline 2014 & & $7,63-12,93^{*}$ & $0,10-0,66$ & $0,03-0,15^{*}$ \\
\hline 2014 & - Vinnytsia region [14] & $14,1-57,5$ & $0,011-0,740$ & $0,05-0,16$ \\
\hline 2013 & - Ivano-Frankivsk region [1] & $4,5-58,3$ & $0,0005-0,009$ & $0,3-8,9$ \\
\hline 2016 & - Ivano-Frankivsk region [4] & $9,2-58,7$ & $0,0011-0,0088$ & $1,7-7,9$ \\
\hline 2015 & - Kyiv region [3] & $1,2-30,6$ & $0,02-0,096$ & $0-0,40$ \\
\hline
\end{tabular}




\begin{tabular}{|c|l|c|c|c|}
\hline 2015 & - Kirovograd region [3] & 23,75 & 0,20 & 0,009 \\
\hline 2015 & - Zhytomyr region [3] & $1,2-23,75$ & $0,02-0,20$ & $0,14-0,42$ \\
\hline 2015 & - Chernihiv region [3] & 110,0 & 0,06 & 0,09 \\
\hline 2015 & - Poltava region [3] & 30,6 & 0,096 & 0,008 \\
\hline 2014 & - Poltava region [15] & $52,4-189,0$ & & \\
\hline 2011 & - Cherkassy region [11] & $3,85-5664$ & & \\
\hline
\end{tabular}

Note: ${ }^{*}$ - a significant difference is established between the content of nitrogen compounds in the well water of the Chernivtsi region for the indicators 2014, compared with the indicators 2013. It established using the Mann-Whitney U-criterion $(p<0.05)$

It is noted that the contamination of well water by of nitrogen compounds has caused by inflow of groundwater of domestic wastewater, nitrogen and organic fertilizers, non-compliance with sanitary regulations temporary storage of obsolete prohibited, unknown pesticides, and violation of using rules of the crop protection chemicals during processing of crops [1]. It is proved that the most polluted of wells located near agricultural land, farms, poultry farms, or their owners do not adhere to the sanitary and hygienic norms of private farming and care of wells. Therefore, another major cause of contamination of well water is bad sanitary condition of the wells (absence of or damage waterproof layer, roofing, covers, public buckets) proximity is less than 20 meters to sources of pollution (street toilets, cesspool or silo pit, compost storages), as well as not carrying out more than one year of repair, cleaning and decontamination of wells, as provided by the sanitary rules [11].

We analyzed several indicators of agro-loading of certain areas of Chernivtsi region, namely: the amount bringing of mineral (in particular, nitrogen) fertilizers under agricultural crops, the area of agricultural lands designated for crop sowing, agro-chemical and agro-ecological bonitets indexes and the cattle stock.

Diagrams of the projections of variables on the factor-plane 1-2 (fig. 2) were constructed using the method of the main components. It was established that in $2013 \mathrm{NO}_{3}{ }^{-}$and $\mathrm{NH}_{4}{ }^{+}$concentrations have forming a joint association with indicators such as agrochemical and agro-ecological bonite indexes, indicating the synergism of their dispersion. Instead, in 2014, the content of ammonia ions and nitrate ions is associated with the indicator of cattle stock. The $\mathrm{NO}_{2}{ }^{-}$concentration has forming a low load on the factor plane of 1-2 $(<1 / 3)$ both in 2013 and in 2014. Thus, combining this variable into one association with other factors is incorrect.

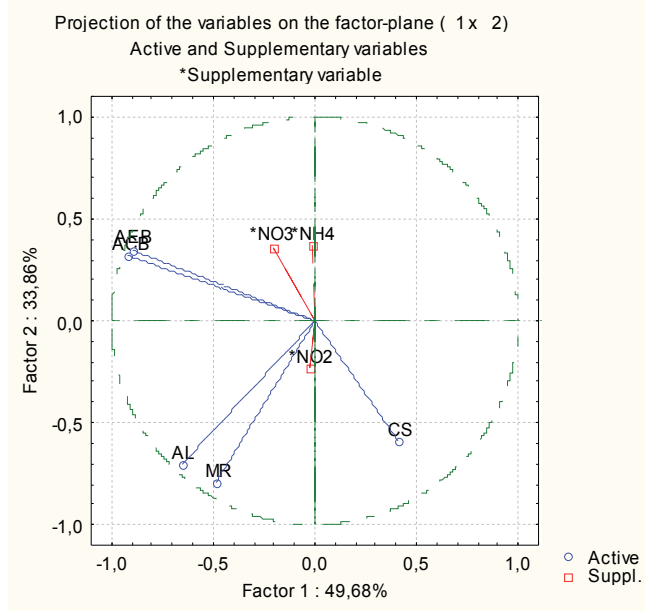

2013

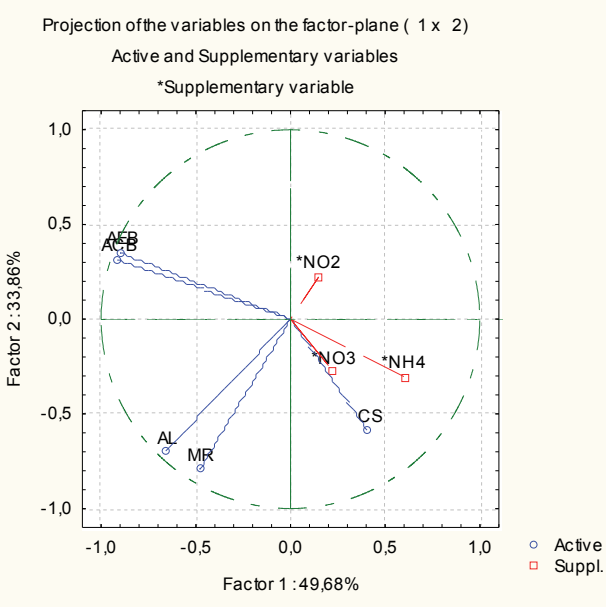

2014

Fig. 2. Diagrams of projections of the variables on the factor-plane 1-2

$M F$ - the amount bringing of mineral (in particular, nitrogen) fertilizers under agricultural crops, hundredweight; $A L$ - the area of agricultural lands designated for crop sowing, hectare; ACB - agro-chemical bonite; AEB - agroe-cological bonite; CS - cattle stock. 
Knowing that the presence of nitrates indicates about old pollution, the ammonium compounds indicates about fresh pollution, and nitrates indicates about relatively recent pollution [10], then it can be said that the well waters of the Chernivtsi region are the result of constant prolonged pollution of groundwater.

Thus, the content of the components of Nitrogen is not stable in the well waters of the Chernivtsi regions and is exposed to agro-ecological stress.

\section{Conclusions}

It is shown that the drinking water of Northern Bukovina belongs to the category of clean and fairly clean water and has a favorable ecological status. However, within these characteristics certain changes occurred by the indacator concentration of nitrogen-containing compounds.

\section{Bibliography}

1. Harasymchuk V., Pankiv R., Kaminetska B. (2013). Hidrodynamichne modeliuvannia ta otsinka ekoloho-heokhimichnykh kharakterystyk gruntovykh vod silskoi mistsevosti (na prykladi s. Novosilka Lvivskoi oblasti). Heolohiia i heokhimiia horiuchykh kopalyn. № 1-2. S. 78-87. [In Ukrainian].

2. Yakovliev V.V. (2011). Inzhenerni zakhody dlia pokrashchennia yakosti kolodiaznykh vod. Visnyk Natsionalnoho tekhnichnoho universytetu «Kharkivskyi politekhnichnyi instytut». № 65 (15). S. 86-92. [In Ukrainian].

3. Kravchenko M.V. (2015). Fizyko-khimichnyi analiz pryrodnoi pytnoi vody riznykh dzherel vodopostachannia. Ekolohichna bezpeka ta pryrodokorystuvannia. № 3(19). S. 52-60. [In Ukrainian].

4. Hoivanovych N.K., Monastyrska S.S., Antoniak H.L. (2016). Otsiniuvannia yakosti krynychnykh vod deiakykh naselenykh punktiv Dolynskoho raionu za vmistom spoluk azotu. Naukovyi visnyk NLTU Ukrainy. Vyp. 26.7. - S. 202-207. [In Ukrainian].

5. Nitratne zabrudnennia dzherel pytnoi vody v Ukraini: doslidzhennia VEHO «Mama-86» 2001-2008 roky. Kyiv, 2009. 16 s. [In Ukrainian].

6. Hutsuliak D., Hutsuliak Yu. (2004). Vodni resursy Karpat, dzherela yikh zabrudnennia ta yoho nehatyvni naslidky. Naukovyi visnyk Ukrainskoho derzhavnoho lisotekhnichnoho universytetu. Vyp. 14.3. S. 252-258. [In Ukrainian].

7. Cherneha A.M., Ishchenko V.A. (2016). Doslidzhennia skladu pytnoi vody $z$ dzherel detsentralizovanoho vodopostachannia. Visnyk VPI. № 4. S. 32-35. [In Ukrainian].

8. Vieru N.D., Vieru N.P. (2010). Levels of Magnesium, Calcium and other inorganic compounds in water of the wells in rural areas of Botoşani county. Present environment and sustainable development. № 4. C. 399-406.

9. Mahasim N.W., Saat A., Hamzah Z. et al. (2005). Nitrate and phosphate contents and quality of well water in North-eastern districts of Kelantan. SKAM18. International Education Centre, University Teknologi (MARA). India. P. 1-8.

10. Derzhavni sanitarni normy ta pravyla «Hihiienichni vymohy do vody pytnoi, pryznachenoi dlia spozhyvannia liudynoiu»: DSanPiN 2.2.4-400-10. [In Ukrainian].

11. Petruk V.H., Haidei Yu.A., Vovk O.S. (2011). Analiz stanu yakosti pytnoi vody u kolodiaziakh m. Vinnytsi ta Vinnytskoi oblasti. Zbirnyk naukovykh prats VNAU. № 8 (48). S. 119-123. [In Ukrainian].

12. Senenko N.B., Storozhenko D.O., Senenko A. I., Pysarenko P.V. (2014). Sposib ochystky pytnoi vody vid nitrat-ioniv. Visnyk Poltavskoi derzhavnoi ahrarnoi akademii. № 1. S. 91-95. [In Ukrainian].

13. Svoiak N.I. (2014). Doslidzhennia zabrudnennia nitratamy pytnoi vody z detsentralizovanykh dzherel vodopostachannia v Cherkaskii oblasti. Visnyk ChDTU. № 4. S. 113-117. [In Ukrainian].

14. Nikolaev A.M. (2014). Vpliv poligoniv tverdikh pobutovikh vidkhodiv mista Chernivtsi na pidzemni i poverkhnevi vodi, Irunti ta donni vidkladi vodotokiv. Geopolitika i ekogeodinamika regionov. Nauchniy zhurnal. T. 10. Vip. 2. S. 664-667. [In Russian].

15. Fesenko O.H. (2014). Kharakterystyka nitratnoho zabrudnennia poverkhnevykh i pidzemnykh vod Poltavskoho rehionu. Visnyk Poltavskoi derzhavnoi ahrarnoi akademii. № 1. S. 121-124. [In Ukrainian]. 
16. Oleksiichuk T.V., Solovei T.V. (2010). Mineralni formy azotu u pidzemnykh vodakh baseinu richky Prut $v$ mezhakh Chernivetskoi oblasti. Naukovi zapysky Vinnytskoho derzhavnoho pedahohichnoho un-tu imeni M. Kotsiubynskoho. Ser. Heohrafiia. Vyp. 20. S. 23-31. [In Ukrainian].

17. Shevchuk Yu.F. (2005). Suchasnyi stan detsentralizovanoho vodopostachannia m. Chernivtsi. Hidrolohiia, hidrokhimiia i hidroekolohiia. T. 9. S. 217-223. [In Ukrainian].

18. Shevchuk Yu., Nykolaiev A., Shevchuk A. (2014). Yakist pytnoi vody netsentralizovanoho vodopostachannia v m. Chernivtsi. Naukovi zapysky TNPU. № 1 (36). S. 182-187. [In Ukrainian].

19. HOST R 51593-2000 «Voda pytna. Vidbir prob». [In Ukrainian].

20. Kostyshyn S.S., Holovchenko L.Iu., Dzenzerska O.M., Buzhdyhan O.la. (2015). CNP-monitorynh richkovykh ekosystem (na prykladi Chernivetskoi oblasti): navchalnyi posibnyk. (Ed). S.S. Rudenko. Chernivtsi: Misto. $152 \mathrm{~s}$. [In Ukrainian].

21. Trapeznikova L.V., Chundak S.Iu., Monych I.I. (2014). Ekolohichnyi stan gruntovykh vod baseinu r. Vela. Nauk. visnyk Uzhhorod. un-tu (Ser. Khimiia). № 1 (31). C. 81-86. [In Ukrainian].

22. Mastitskiy S.E. (2009). Metodicheskoe posobie po ispol'zovaniyu programmy STATISTICA pri obrabotke dannykh biologicheskikh issledovaniy. Minsk: RUP «Institut rybnogo khozyaystva». $76 \mathrm{~s}$. [In Russian].

23. Derzhavni sanitarni normy ta pravyla «Hihiienichni vymohy do vody pytnoi, pryznachenoi dlia spozhyvannia liudynoiu»: DSanPiN 2.2.4-400-10.

24. Khilchevskyi V.K., Savytskyi V.M., Krasova L.A., Honchar O.M. (2012). Polovi ta laboratorni doslidzhennia khimichnoho skladu vody richky Ros: navchalnyi posibnyk; V.K. Khilchevskoho (Ed.). Kyiv: Kyivskyi universytet. $143 \mathrm{~s}$. [In Ukrainian]. 